\title{
Phraseologization as a process of semantic change
}

\author{
Elena Sánchez López \\ Universitat d'Alacant. Departament de Filologia Catalana \\ elena.sanchez@ua.es
}

Received: June 24, 2015

Accepted: August 10, 2015

\begin{abstract}
On the one hand, phraseology has sorted out how to describe Phraseological meaning from a synchronic perspective. On the other, cognitive diachronic linguistics has thoroughly described the process of semantic change and the mechanisms leading to it, but mostly focusing on grammaticalization. The aim of the present paper is to bring together these two perspectives in order to account for the existence of Phraseological Units, i.e. the emergence of Phraseological Meaning. This integration of perspectives will require a well defined theoretical framework. First of all, we will establish the definition of PhU and the scope of Phraseological meaning. Then, we will compare grammaticalization to phraseologization process. In this comparison, we will pay special attention to the new role assigned to inference as a mechanism leading to semantic change. Finally, we will apply the developed theoretical framework to an actual PhU: al peu de la lletra.
\end{abstract}

Keywords: phraseology; phraseologisation process; semantic change; diachronic cognitive semantics; pragmatics.

Resum. La fraseologització com a procés de canvi semàntic

Per una part, la fraseologia ha aconseguit definir el significat fraseològic des d'una perspectiva sincrònica. Per l'altra, la lingüística cognitiva diacrònica ha descrit el procés de canvi semàntic i els mecanismes que el provoquen, però centrant-se sobretot en el procés de gramaticalització. L'objectiu del present article és conjugar aquestes dues perspectives a fi de retre compte de l'aparició d'Unitats Fraseològiques, és a dir, el sorgiment del significat fraseològic. La integració d'aquestes perspectives requerirà un marc teòric ben definit. En primer 1loc, establirem la definició d'unitat fraseològica i l'abast del significat fraseològic. Després, compararem els processos de gramaticalització i de fraseologització. En aquesta comparació, pararem especial atenció al nou paper que s'ha assignat a la inferència com a mecanisme provocador del canvi semàntic. Finalment, aplicarem el marc teòric desenvolupat a una unitat fraseològica real: al peu de la lletra.

Paraules clau: fraseologia; procés de fraseologització; canvi semàntic; semàntica cognitiva diacrònica; pragmàtica. 


\section{Table of Contents}
1. Introduction
4. Concluding remarks
2. Theoretical framework:
perspective shift
References

3. Phraseologization and Phraseological

change: al peu de la lletra

\section{Introduction}

Phraseology was initially seen as an anecdotal phenomenon with anomalous features, just appealing for folklorists. Afterwards, it aroused the interest of linguists, who focused mainly on its structure and its taxonomy. Nowadays, within the framework of pragmatics and cognitive linguistics, we can see that much of what was traditionally considered arbitrary and difficult to classify is in fact systematic and motivated. We just have to adopt the right approach and pay attention to context and diachrony.

The current stage of a language is the end-result of an evolutionary process over time, i.e. of a diachronic process. This statement is especially relevant for Phraseological Units (PhU), since they still reflect their point of origin. As lexical relicts from an earlier language stage - where they were created-, they are evidently the result of language change. Thus, their formation process, phraseologization, can be considered as a process leading to semantic change: a complex process yielding units with new semantic features. Despite its intrinsic interest, few studies have been devoted to it.

In the area of Iberian Studies we cannot find research works dealing specifically with semantic change connected to phraseological units. In contrast, historical evolution of monolexical words has been thoroughly investigated (e.g. Martines Peres 2000a, 2000b, 2012a, 2012b, 2013, 2014, 2015 for Catalan words). From this perspective, we can even find some papers on formation of polylexical elements (Garachana 2012, 2014) or of lexical units on the basis of more than one element (Buenafuentes de la Mata 2002). Martines' remark stating that "cognitive diachronic semantics, with the increasing contribution of pragmatics and cultural history, can open new paths to the field of observation and explanation of the generation of new meanings" (Martines Peres 2015) was the initial motivation of this paper.

In the field of phraseology, a few studies have dealt with the evolution of PhU. Burger (1996), Baranov and Dobrovol'skij (1996), Howarth (2000), Sánchez (2013) and Sánchez \& Fuster $(2012,2014)$ have approached the phraseologization process, while Dräger (2012) and Sánchez \& Fuster (2012, 2014) have addressed phraseological change. These works are very important, since they claim the existence of these processes and the necessity of a diachronic approach towards phraseology, but they do not really go into their causes, triggers or mechanisms.

In addition to them, linguists aiming to analyse $\mathrm{PhU}$ had to include processes in their descriptions, to account for their current features. For instance, Corpas (1996: 21-27) names several $\mathrm{PhU}$ features, such as institutionalization, stability and idioma- 
ticity resulting from processes connected to language evolution. Ruiz Gurillo (1997: 85-104) thoroughly describes fixation and idiomaticity as main features of $\mathrm{PhU}$ and reflects on the processes leading to them. Timofeeva (2012) adopts a similar position, despite not adopting a diachronic perspective, she refers to processes (e.g. phraseologization, motivation) in order to determine and account for phraseological meaning. Her approach is basically synchronic, but her exhaustive descriptive model of phraseological meaning is a key starting point for our diachronic analysis.

In the field of cognitive diachronic linguistics, the main focus has been placed on grammaticalization and its associated changes. Thus, semantic change has initially been studied in connection to lexical words becoming grammatical words. Nevertheless, its findings (e.g. the role of metaphor and metonymy as "mechanisms" of semantic change) tend to spread out of this domain. In addition, the resemblance between grammaticalization and phraseologization has been pointed out by several researchers (Pérez Saldanya 1997; Pérez Saldanya \& Salvador 1995; Cuenca 2000; Ruiz Gurillo 2001, 2010).

However, we cannot find a clear precedent for the description of processes leading to the emergence of Phraseological meaning. On the one hand, phraseology has sorted out how to describe Phraseological meaning from a synchronic perspective (Ruiz Gurillo 1997, 1998, 2001; Timofeeva 2012; Burger 1996; Baranov \& Dobrovol'skij 1996; Dobrovol'skij 2005). On the other, cognitive diachronic linguistics has thoroughly described the process of semantic change and the mechanisms leading to it (Heine et al. 1991; Barcelona 2000; Hopper \& Traugott 2003; Traugott and Dasher 2002), but mostly focusing on grammaticalization. We will now try to integrate these two perspectives and retain the best of both worlds.

The aim of the present paper is to bring together these two perspectives (phraseology and cognitive diachronic linguistics) in order to account for the existence of Phraseological Units, i.e. the emergence of Phraseological Meaning. This integration of perspectives will require a well defined theoretical framework. First of all, we will establish the definition of PhU and the scope of Phraseological meaning. Then, we will compare grammaticalization to phraseologization process. In this comparison, we will pay special attention to the new role assigned to inference as a mechanism leading to semantic change. Finally, we will apply the developed theoretical framework to an actual PhU: al peu de la lletra. ${ }^{1}$

\section{Theoretical framework: perspective shift}

In spite of being evidently a product of language change, $\mathrm{PhU}$ have not been analysed under the light of semantic change theory. This might be attributed to the fuzzy definition of this kind of units and to the scarce data on historical evolution of PhU. We will provide a clear and broad definition of $\mathrm{PhU}$ in addition to some diachronic data in order to show that the emergence and change of follow regular patterns, namely, those of semantic change.

1. It is a phraseological unit in Catalan language, literally meaning to the foot of the letter. Its phraseological meaning will be discussed at the end of the paper. 


\subsection{The unit: a (Poly)lexical unit}

The field of Phraseology is characterized by producing a great amount of literature on the features and taxonomy of its units. It is not the aim of this paper to reflect this discussion. We just would like to acknowledge that our conception of $\mathrm{PhU}$ was coined by Ruiz Gurillo (1997, 2001). In spite of being the most clarifying and inclusive PhU description from a synchronic perspective, we will need a still broader definition for our diachronic approach. For the purpose of this paper, $\mathrm{PhU}$ is understood as (poly)lexical unit.

As we were saying, phraseological units are multiword lexical units, in Burger's (2010:15-32) words, they are items characterized for their polylexicality and their fixity. ${ }^{2}$ While he finds polilexicality easy to identify, he admits fixity is not so simple to prove. Therefore, he names visible features that can make it more tangible, such as generalized use ${ }^{3}$, psycholinguistic fixity (speakers conceiving it as a unit), structural fixity (with variations) and pragmatic fixity. In addition to the essential features, he also mentions idiomaticity as a secondary trait. He refers to "semantic idiomaticity", i.e. the difference between phraseological meaning and the meaning resulting from the combination of its constituent parts.

Timofeeva (2012) completes this definition with the description of phraseological meaning. ${ }^{4}$ To really capture all its components, she presents a complex "macrocomponential" model, including 6 different information blocks: Denominative block, Motivational block (or Image), Rationalized Evaluation block, EmotiveEmotional Evaluation block, Style block and Grammar block. Style and Grammar blocks are important, but we consider them self-explanatory. The identification of the Evaluation blocks is a great contribution to phraseology by Timofeeva. They are pragmatic features and depend on the Image.

The Image is a key component of phraseological meaning. In her book, Timofeeva speaks of motivation, motivational block and Image component. We conceive motivation as a cognitive process, as defined by Piirainen (2012: 48), it consists in activating "certain knowledge structures to make sense of the use of a given idiom in the meaning conventionally ascribed to it. The relationship between the two conceptual levels, between the mental image evoked by the lexical structure and the figurative meaning, becomes comprehensible to them". The result of the process is an Image connecting the lexical structure (the Form) and the (denominative) Meaning. Therefore, we prefer to designate the component as Image and the process as Motivation.

From our view, the Phraseological sign consists of three parts: Form (noncompositional meaning), (denotative) Meaning and (conventionalized) Reality. Synchronically, the Image (emerging from the motivation process) is the component holding them together. As we can see in Figure 1, the connection between Meaning and Form is established through the Image component, on the basis of Reality (the world knowledge and the knowledge of the context).

2. Polilexikalität and Festigkeit in the original in German.

3. Gebräuchlichkeit in the original in German.

4. Note that this description refers to a prototypical $\mathrm{PhU}$, i.e. a polylexical unit with figurative meaning. 


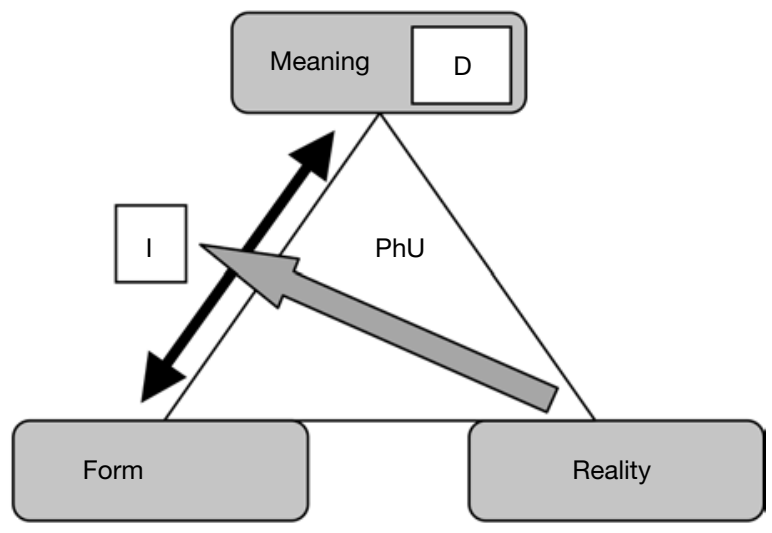

Figure 1. Phraseological sign.

The information blocks described by Timofeeva (2012) are just the first meaning level, i.e. the conventionalized meaning of the $\mathrm{PhU}$. If we see the isolated $\mathrm{PhU}$, we can recognize these features, because they are fixed and form part of language system. From a systemic perspective, since we can simultaneously see its Form - and the meaning resulting from the combination of its constituents- and its denotative phraseological Meaning, a PhU is by definition polysemous. In a discourse context, phraseological Meaning can be reinforced by contextual elements, but it may also be cancelled, the hearer being thus leaded to the non-compositional meaning of the expression.

In addition, this kind of units has also fixed pragmatic values. As Levinson (2004: 263) claims, pragmatic inferences end up embedded in semantic representations causing pragmatic "intrusion". These inferences are easier to see in $\mathrm{PhU}$ than in monolexical units, mostly for their Image component. From a systemic perspective, according to Timofeeva (2012: 248), PhU present Conventionalized Implicatures and Generalized Conversational Implicatures. Inserted in a discourse, its Generalized Conversational Implicatures, depending on their degree of conventionalization, may be cancelled or modified and new Particularized Conversational Implicatures may. Since they are not part of language system, they are synchronically no so relevant for phraseology. However, from a diachronic perspective, they are quite important, since they might eventually become generalized and even conventionalized. But we do not want to jump to diachrony yet, let's go step by step.

\subsection{The process: Phraseologization}

Phraseologization consists of all the changes affecting a free word combination until it becomes a frozen Phraseological unit (pure idiom ${ }^{5}$ ). At this point, we would

5. In Howarth's (2000: 216) terminology. 
like to remark that the prototypical PhU is not the frozen one, but the one with figurative meaning ${ }^{6}$ (as described above).

Cognitive diachronic linguistics has traditionally focused on the grammaticalization $^{7}$ of words. Several authors (Pérez Saldanya 1997; Pérez Saldanya \& Salvador 1995; Cuenca 2000; Ruiz Gurillo 1997, 2001, 2010) have pointed out the resemblance between grammaticalization and phraseologization process. We agree that these two processes have a lot in common, but they differ in an important aspect. While grammaticalization involves lexical words becoming grammatical words (or grammatical words changing its meaning), phraseologization is concerned with phrases turning into (poly)lexical units. We could call it lexicalization, but, attending to tradition and to the fact that this term is used for conveying different meanings, ${ }^{8}$ we will designate it as phraseologization. ${ }^{9}$

From our perspective, phraseologization can be seen in 4 stages, ${ }^{10}$ as indicated in Table 1. On the top row, we name the resulting items according to the terminology we consider more appropriate. However, since in English language they usually receive other names, I also include the most common denomination in the bottom row.

Grammaticalization and phraseologization share their main features (c.f. Company 2012: 668), with some particularities due to the different levels they act at. In Table 2 we compare the meaning and form changes in a grammaticalization process (as described by Company 2012: 688) to those in a phraseologization process (as observed in real examples).

As we can see, they coincide at their respective levels. Items (i), (iv), (xi) and (xiv) are worth a comment. Logically, regarding phraseology, (i) the phrase-

Table 1. Stages of the phraseologization process

\begin{tabular}{lccc}
\hline \multicolumn{4}{c}{ Phraseologization (systemic level) } \\
\hline $\begin{array}{l}\text { 1. Free word } \\
\text { combination }\end{array}$ & $\begin{array}{c}\text { 2. Restricted word } \\
\text { combination }\end{array}$ & $\begin{array}{l}\text { 3. Phraseological } \\
\text { Unit with figurative } \\
\text { meaning }\end{array}$ & $\begin{array}{l}\text { 4. Frozen } \\
\text { Phraseological Unit }\end{array}$ \\
\hline Phrase & Collocation & $\begin{array}{l}\text { Idiom with figurative } \\
\text { meaning }\end{array}$ & Pure idiom \\
\hline
\end{tabular}

6. Cf. Ruiz Gurillo (1997, ch. 3).

7. "Grammaticalization is usually defined as the process by which a lexical item or a sequence of items becomes a grammatical morpheme, changing its distribution and function in the process (Meillet [1913] 1958; Givón 1979; Lehmann 1982; Heine and Reh 1984; Heine, Claudi, and Hünnemeyer 1991a, 1991b; Hopper and Traugott 1993)" (Bybee 2007)

8. "Broadly defined as the adoption of concepts into the lexicon, it has been viewed by syntacticians as the reverse process of grammaticalization, by morphologists as a routine process of word-formation, and by semanticists as the development of concrete meanings" (Traugott and Brinton 2005).

9. Nevertheless, we are aware of the fact that this very name reflects the dominating synchronic approach in phraseology. Since it is not conceived as phrase becoming a lexical unit, but as a set of words becoming (conceptually) a phrase.

10. This progression is based on the non-discrete classification of PhU by Ruiz Gurillo (1997, ch. 3). 
Table 2. Meaning and changes in grammaticalization process (Company 2012: 688) compared to those in phraseologization process]

Grammaticalization (Company 2012: 688).

Phraseologization

The equal sign (=) means that the consequence

is a direct result from the preceding case

(i) Weakening or loss of lexical-referential meaning $=$ increase of more abstract grammatical meaning = decategorization/ recategorization

(ii) Extension across contexts = generalization and frequently obligatorification of the sign = increase of use = less diatopic variation.

(iii) Lessening of autonomy = weakening or loss of morphosyntactic freedom.

Weakening or loss of phrase meaning $=$ increase of more abstract lexical-meaning = it ceases to act as a phrase

Extension across contexts $=$ generalization of the sign $=$ increase of use as a unit.

Lessening of autonomy $=$ weakening or loss of Formal freedom.

(iv) Freeing of contextual restraints = growth in Freeing of contextual restraints = growth in frequency.

(v) Reduction of scope $=$ intrapositional predication or intra-word scope. frequency.

Reduction of scope $=$ its components are fixed

(vi) Grammatical integration = paradigmatization. Grammatical integration = Paradigmatization the new function implies a new category, in this case is its inclusion as an adverb, and adjective, etc. (Grammar Component by Timofeeva 2012).

(vii) Frequently, but not necessarily, univerbation: two words = one word.

Could happen, but (in Catalan) we will not consider it as $\mathrm{PhU}$ anymore.

(viii) Frequently, but not necessarily, erosion and Could happen, especially in stress languages. loss of phonological weight.

(ix) Layering: a functional domain, over time, may accumulate more than one construction to express that domain.

(x) Divergence: the same etymon splits into different analysis.

(xi) Persistence of syntactic-semantic etymology: the original meaning, quite weakened, usually persists when grammaticalization progresses, and, somewhat paradoxically, that etymological meaning facilitates the advancement to new contexts.

Layering: secondary naming condition.

(xii) More polysemy.

Divergence (over time).

(xiii) Renewal of already extant categories.

(xiv) Lexicalization, understood in two senses: on the one hand, the lexicon as well as dictionaries are enlarged because the form or construction, having new functions and meanings, needs more specifications into the lexicon, and the lexicographic entry must be enlarged. On the other hand, there is lexicalization because of loss of transparency, or opacity, between the two faces of the sign or between the sign and its contexts of use, and the new reinterpreted sign must be specified into the lexicon.
Persistence of Form and Meaning: the original non-compositional meaning (Form), usually persists when phraseologization progresses. The Image created from speakers to motivate the denotative Meaning facilitates the advancement to new contexts.

More polysemy.

Renewal of already extant meanings.

Lexicalization, understood in two senses: on the one hand, the lexicon as well as dictionaries are enlarged because the form or construction, having new functions and meanings, needs more specifications into the lexicon, and the lexicographic entry must be enlarged (or included). On the other hand, there is lexicalization because of loss of transparency, or opacity, between the two faces of the sign or between the sign and its contexts of use, and the new reinterpreted sign must be specified into the lexicon. 
Table 3. Acquisition of new grammatical meanings (Heine 2002: 86) compared to acquisition of new lexical meanings

\begin{tabular}{|c|c|c|c|}
\hline \multicolumn{3}{|c|}{$\begin{array}{l}\text { Scenario of acquisition of new grammatical meanings } \\
\text { (Heine 2002: 86) }\end{array}$} & \multirow{2}{*}{$\begin{array}{l}\text { Phraseologization } \\
\text { process (3.1.) } \\
\begin{array}{l}\text { Stage (lexical } \\
\text { meanings) }\end{array}\end{array}$} \\
\hline $\begin{array}{l}\text { Stage (grammatical } \\
\text { meanings) }\end{array}$ & Context & $\begin{array}{l}\text { Resulting } \\
\text { meaning }\end{array}$ & \\
\hline I. Initial stage & Unconstrained & Source meaning & $\begin{array}{l}\text { 1. Free word } \\
\text { combination }\end{array}$ \\
\hline II. Bridging context & $\begin{array}{l}\text { Specific context giving } \\
\text { rise to an inference } \\
\text { in favour of a new } \\
\text { meaning }\end{array}$ & $\begin{array}{l}\text { Target meaning } \\
\text { foregrounded }\end{array}$ & $\begin{array}{l}\text { 2. Restricted word } \\
\text { combination }\end{array}$ \\
\hline III. Switch context & $\begin{array}{l}\text { New context which is } \\
\text { incompatible with the } \\
\text { source meaning }\end{array}$ & $\begin{array}{l}\text { Source meaning } \\
\text { backgrounded }\end{array}$ & $\begin{array}{l}\text { 3. Phraseological Unit } \\
\text { with figurative meaning }\end{array}$ \\
\hline IV. Conventionalization & $\begin{array}{l}\text { Target meaning no } \\
\text { longer needs to be } \\
\text { supported by the } \\
\text { context that gave rise } \\
\text { to it; it may be used in } \\
\text { new contexts }\end{array}$ & Target meaning only & $\begin{array}{l}\text { 4. Frozen } \\
\text { Phraseological Unit }\end{array}$ \\
\hline
\end{tabular}

meaning is lost and a lexical meaning appears (although they may coexist). (iv) The phrase belongs then to a new category, assimilable to those of lexical units. (xi) Its Form (non-compositional meaning) and its (denotative) Meaning (comparable to the syntactic-semantic etymology in the grammaticalization process) persist. They are fixed, but due to the progression of time, the real etymology is not recognized anymore. Thus, the speakers tend to remotivate its connection and create an Image. This Image facilitates the advancement to new contexts. (xiv) The new created PhU is lexicalized: it has to be included in the dictionary, thus enlarging the lexicon of a language, and the loss of transparency, or opacity, between the two faces of the sign or between the sign and its contexts of use, and the new reinterpreted sign must be specified into the lexicon.

As can be observed in Table 3, the stages in the acquisition of grammatical meanings in connection to grammaticalization process (Heine 2002: 86) are identical to those of acquisition of lexical meanings by a phraseologization process. In addition, context conditions as well as resulting meaning are also applicable to both processes. Even the concepts source and target meaning could be assimilable to Form (non-compositional meaning) and (denotative) Meaning.

\subsection{Mechanisms: Implicature, reanalysis and analogy}

Mechanisms triggering phraseologization have not been diachronically studied. Ruiz Gurillo (2001) established that phraseology was not an anomalous phenomenon i.e. that it followed the creation patterns of general language. Logically, 
since metaphor and metonymy were considered as the main mechanisms for language creativity and semantic change (cf. e.g. Ruiz Gurillo, 2001; Baranov and Dobrovol'skij 1996: 52-ff., cited by Timofeeva ${ }^{11}$ 2012: 132-139), they were also responsible for acquisition of new semantic values regarding phraseologization.

These researchers followed the dominant view that metaphor and metonymy were the mechanisms triggering semantic change. It seemed, indeed, to be consistent with the phenomenon they were observing. The point is, they were observing it synchronically and isolated. They could see an element from the past (the Form) and its evolution (the canonical Meaning) and tried to explain the relation between them by reconstructing the process. However, with the help of text corpora we could verify that it does not coincide with the actual process, as you will see in section 3 .

Timofeeva (2012) opened the way to identify the mechanisms of semantic change regarding PhU, when she included CI, GCI and PCI as part of phraseological meaning. In addition, an important line of research (c.f. Traugott and Dasher 2002) identified the regular patterns in meaning change and found out that implicature was the crucial mechanism of semantic change. On this basis, and with our observation of corpus data, our view is that Historial Pragmatics (c.f. Traugott 2004) plays a major role in phraseologization.

According to this line of research, meaning change occurs in discourse, i.e. in the process of creating and interpreting meanings in specific contexts. In this process, new implicatures may arise and, if they become conventionalized, a new meaning emerges. Fixation of a new interpretation of a linguistic expression is designated as semantic reanalysis. The new meaning is supported and spreads through on the basis of analogy. These are roughly the principles of the Invited Inferencing ${ }^{12}$ Theory of Semantic Change (IITSC). In the following section we will observe phraseologization under the light of this theory.

\section{Phraseologization and Phraseological change: al peu de la lletra}

Before starting our diachronic description, we would like to remark that this kind of studies is always an approximation to reality, on the basis of the data we have nowadays. The aim is to identify the oldest attestation, assume that it is the origin and explain its evolution attending to gathered data. For this purpose, we used corpora representing three different stages of the Catalan language, namely, Corpus Informatitzat de la Gramàtica del Català Antic (CIGCA) ${ }^{13}$, Corpus Informatitzat de la Gramàtica del Català Modern (CIGCatMod) ${ }^{14}$ and Corpus Textual Infomatitzat de la Llengua Catalana (CTILC). ${ }^{15}$

11. We can access the works by Baranov and Dobrovol'skij thanks to their inclusion in Timofeeva's (2012) book, for they are written in Russian.

12. Invited Inference is the equivalent to Particularized Conversational Implicature in Levinson's (2004) terminology.

13. Including Catalan texts from $13^{\text {th }}-16^{\text {th }}$ centuries.

14. Texts from 1601-1833.

15. Texts from 1833-1988. 


\subsection{Phraseologization}

First of all, I would like to make an initial remark: Phraseological Units are not created in a vacuum, they are generated in a determined context. Actually, this context involves at least three different levels: cotext (sentence level), communication situation and physical-historical situation. We could even understand context as "anything that can have an influence on the interpretation of an utterance" (Schmid, 2003). As we are dealing with a systemic phenomenon (not with a particular one), these contexts are to be understood as prototypical sentence, communication and physical-historical contexts. If we connect that with Levinson's (2004: 22) levels of meaning, it would be an Utterance-type-context.

As shown in Table 1, a PhU can go through four stages over time: free combination word (phrase) $>$ Restricted word combination (collocation) $>$ Phraseological Unit with Figurative Meaning (Idiom with Figurative Meaning) > Frozen Phraeological Unit (Pure Idiom). These are all stages a word combination can go through in terms of phraseologization. Note that at stages 1. and 2. speakers perceive them as word combinations, but at stages 3 . and 4 . they are already understood as units. We should not see this transition as a chain of abrupt changes, since all these transformations happen gradually. ${ }^{16}$ In fact, some different stages of the same combination may coexist in time. It is also evident that not every combination goes through all stages: in the course of time some of them stay in one stage, others just disappear. We even could see the same set of words with different values, depending on which synchronic cut we take into consideration.

These reflections are relevant to the discussion on $\mathrm{PhU}$ taxonomy, since a PhU can diachronically change its category or even belong to two (or more) categories at the same time. For instance, a restricted word combination can be considered as a collocation, which can become a completely fixed phrase as time goes by. That is, collocations could diachronically be seen as phrases' ancestors.

The prototypical $\mathrm{PhU}$ is that in stage 3: a polylexical idiomatic unit. We call it prototypical because it is the salient one, since speakers perceive it as anomalous. The Image is quite visible at this stage, conferring it a figurative sense, which makes it a marked expression ${ }^{17}$. This Image component also facilitates analogy to other polylexical units, being responsible for phraseological change.

\subsubsection{First stage: Free word combination (initial stage)}

At an initial stage, the phrase was just a free word combination within a nonconstrained context and it did not present any phraseological meaning. Al peu de (at the foot of) was an already fixed unit, which was usually employed as a preposition with $3 \mathrm{D}$ objects standing at the foot of another 3D object (1).

16. On a synchronic cut, this gradual transition was already pointed out by Ruiz Gurillo (1998: ch. 3), among others.

17. According to Levinson's M-heuristic (2004: 63-85). 
(1) Dementre que ella anava enaixí, guardà e viu en un alt arbre molt bell e molt gran, carregat de moltes flors, e de moltes fulles, e de molts fruits; 1 'arbre era al peu de la muntanya.

'while she was walking, she looked up and saw a tall, very nice and very big tree, loaded with flowers, leaves and fruits; the tree was at the foot of the mountain.

(1271-1274) Llibre de Contemplació, Ramón Llull (CIGCA)

\subsubsection{Second stage: restricted word combination (bridging context)}

The phrase begins to be used in legal documents [s.th. important] al peu de [a legal document], to indicate at the end of the document (2 a-c). At this point, it can already be considered as a restricted word combination, with a pragmatic (phraseological) meaning provided by the context. Since the [items] at the end of the [legal document] are important considerations made by an authority, they had to be read carefully and, if applicable, duly performed. This implies a high degree of exactitude. The target meaning begins to emerge, but is still in the background. Therefore, this could be considered as the bridging context.

Note that not just the cotext is relevant for the emergence of the new meaning. The real world context, where documents were handwritten and dispositions placed at the end of legal documents, is also quite important for the phrase interpretation. Language synchronic cut plays also a significant role, since lletra is primarily understood as written document. While today it would be understood as an alphabet letter.

(2) a. E manaren a mi, Bernat Struch, notari scrivà de jurats, de les dites coses fer lo present acte al peu del dit consell

'And they requested me, Bernat Struch, notary public, to put on the record the said things at the foot of the mentioned council' $\left(15^{\text {th }}\right)$ El Manual de Consells de Gandia a la fi del segle XV (CIGCA)

b. E liurà a mi, dit Bernat Astruch, notari, una cèdula, requerint aquella fos insertada al peu del que dessús ha dit

'And they gave me, Bernat Astruch, notary public, a document, requiring it to be included at the foot of the above said'

$\left(15^{\text {th }}\right)$ El Manual de Consells de Gandia a la fi del segle XV (CIGCA)

c. Com a notari de la dita veguería, fféu acte públich, lo qual acte continua al peu de la dita depositió e enquesta de la dita na Valentina.

'As a notary public of the said area, I put on the records, records that follow at the food of the said deposition and inquiry of the said Miss Valentina'. (15 $\left.{ }^{\text {th }}\right)$ Processos de Crims del segle XV a Lleida (CIGCA)

\subsubsection{Third stage: Phraseological Unit with Figurative Meaning (switch context)}

The phrase is now fixed and the speakers perceive it as a unit. A reanalysis has taken place, since a phrase with a circumstantial complement function has become an adverb of manner. Its Form (compositional meaning) and its phraseological 
Meaning have drifted apart due to language and history evolution. Thus, speakers cannot see its connection anymore, they tend to motivate ${ }^{18}$ it and create the Image. Since the PhU is not the primary means for naming the thing, property, event, etc. it refers to, at this stage, we have a Phraseological Unit with Figurative Meaning ${ }^{19}$ and all the components described by Timofeeva (2012: 201-254).

Linguistically speaking, this would be the switch context, since the target meaning [exactly] is now in the foreground, but the source meaning is still present (3a).

(3) a. Manà que los prínceps y jutges seculars tinguessen cuidado particular de fer cumplir los testaments y últimas voluntats dels defuncts al peu de la lletra

'He ordered to princes and secular magistrates that they should be attentive to make comply deceased's testaments and last wills at the foot of the letter [exactly]'

$\left(16^{\text {th }}\right)$ Història general de Catalunya $-I I$ (CIGCA)

b. Confés que temptat me viu;| però en fi la cortesía| pogué obligar-me a venir, |com ell, al peu de la lletra

'I confess I was tempted to; but eventually courtesy| obliged me to come,| as he did, at the foot of the letter [on foot]'

[Context: Porfiri went to bring Barbara's letter to Valentí. When they have everything prepared to ride back to Alexandria, Valentí says he wants to go on foot.]

(1617) Comèdia famosa de la gloriosa verge i màrtir Santa Bàrbara (CIGCatMod)

c. Puestos, pues, a la ligera y del modo que Avendaño quiso y supo se pusieron en camino de Toledo ad pedem litterae y sin espadas

'Then, light dressed, in the way Avendaño wanted and could, they setted out for Toledo ad pedem litterae [on foot] and swordless'

(ca. 1606) La ilustre fregona, Cervantes

d. Morlà: Es pensen estes senyores que lo que el cartell proposa és tot al peu de la lletra; però li falta la nota.

'Morlà: These ladies think that that proposed in the bill is all at the foot of the letter; but the note is missing.'

$\left(17^{\text {th }}\right)$ Poesies $i$ col $\cdot$ loquis, Pere Jacint Morlà (CIGCatMod)

As the source meaning is still present, the PhU can be defamiliarized, i.e., it can be used in a context favouring the source-meaning (literal) interpretation ( $3 \mathrm{~b}-\mathrm{d})$. This use is not neutral, but humorous ${ }^{20}$. And it is so because the speaker knows that [exactly] is the 'regular' interpretation.

18. Motivation is to be understood as the cognitive process defined in 2 .

19. According to Dobrovol'skij and Piirainen (2005: 14), a unit is considered figurative when it meets two criteria: being an additional naming and having an Image component.

20. Pragmatically speaking, it is so because the acquired GCI are cancelled by the context 
In $(3 \mathrm{~b}, \mathrm{c})$ the unit is used as a synomym of "on foot", because its Form includes the foot of the letter. The speaker finds it funny, since he knows its phraseological meaning and also its solemn origin. In (3c) this origin is even highlighted for the fact of being cited in Latin, the "legal language". However, the "usual" expression in Latin for this meaning was, and still is, ad litteram. The reading in (3b) is not evident for a current reader, but the similar use in the contemporary example (3c) in Spanish confirms our intuition.

In $(3 \mathrm{~d})$, the author creates a context where both readings are activated: there should be a note at the foot [end] of the letter with further [exact] information, but the note is missing. At this stage, the $\mathrm{PhU}$ is polysemous, since the reader can see both the Form (source meaning) and the Meaning (target meaning), although the target meaning is in the foreground. The author takes advantage of this polysemy to create a pun.

\subsubsection{Fourth stage: Frozen Phraseological Unit (conventionalization)}

At the last stage of phraseologization, the PhU is completely fixed, ie, frozen. Its Form, its Meaning and their connection to Reality remain preserved, but it acts as a monolexical unit, displaying just the target meaning. The speakers do not perceive its constituent parts anymore and they just see a normal word (with a signifier and a signified) referring to an object (process, etc.). In this case, defamiliarization becomes impossible, because the non-compositional meaning has disappeared, thus, polysemy is not present anymore. Phraseological change on the basis of Image or Form analogy becomes also improbable. ${ }^{21}$

(4) a. Per açó existía la Diputació del General: pera mantenir lo pacte entre la nació y lo rey; pera fer complir al peu de la lletra lo manat en les Corts; 'For that reason there was a General Deputation: to mantain the pact between nation and king; to make comply at the foot of the letter [exactly] what has been ordered by the Council;'

(1894). Institucions de Catalunya, Salvador Bové (CTILC)

b. Da $\cdot$ Ruf ¿De veras? D· Jos· Sí; cuand prometo, senyora, cumpleixo al peu de la lletra

'Miss Ruf: Really? Mr Jos: Yes, when I make a promiss, my lady, I always fulfill it at the foot of the letter [exactly]'

(1866) Qui al cel escup..., Marcial Busquets (CTILC)

c. Aquesta Profecia se ha cumplert al peu de la lletra, y fou feta set cents anys antes de la vinguda de Christo

'This Prophecy was [exactly] to the foot of the letter complied [fulfilled], and it was made seven hundred years before Christ's birth'

(1837) Promtuari catolich, Josep Arnautó (CTILC)

21. Assuming it is completely frozen, phraseological change on the basis of Image or Form analogy or defamiliaration are imposible, but in actual language an image rest remains usually available. Maybe for the fact that its components are written separately. 
At this point, it is a (poly)lexical unit with no special pragmatic value and the cycle starts again. As we can see (4a), it is likely to be combined with complir 'comply' and laws or regulations (4a), but it extends its scope and can be also used with promesa 'promise' (4b) or profecia 'prophecy' (4c).

\subsection{Phraseological change}

By adopting a diachronic approach to phraseology, we can not only explain the creation process of PhU, but also their modifications through time, that is, phraseological change. ${ }^{22}$ Except for some exceptions (Dräger 2012, Sánchez \& Fuster 2012 , 2014), this set of processes have been traditionally neglected by researchers. Nevertheless, we find it especially interesting, since it deals with the way historical and language change affect a polylexical linguistic element.

The following description of the process is mainly based upon Dräger's (2012: 204-ff) description of the three levels of Phraseological change and their interaction. In addition, we take into account the components of Phraseological meaning as described by Timofeeva (2012) and our observations of the phenomenon in corpora (c.f. Sánchez \& Lozano 2015).

We should not forget that, once fixed, a PhU is a lexical unit, thus, it can evolve just like a monolexical word, by acquiring new meanings. However, especially while being in stage 3 , it is also a special kind of lexical unit, since it conveys a Denotative (non-compositional) Meaning through a (compositional) Form. Speakers tend to motivate this connection through the Image, basing on the Reality (world knowledge and knowledge of the context). But the PhU was

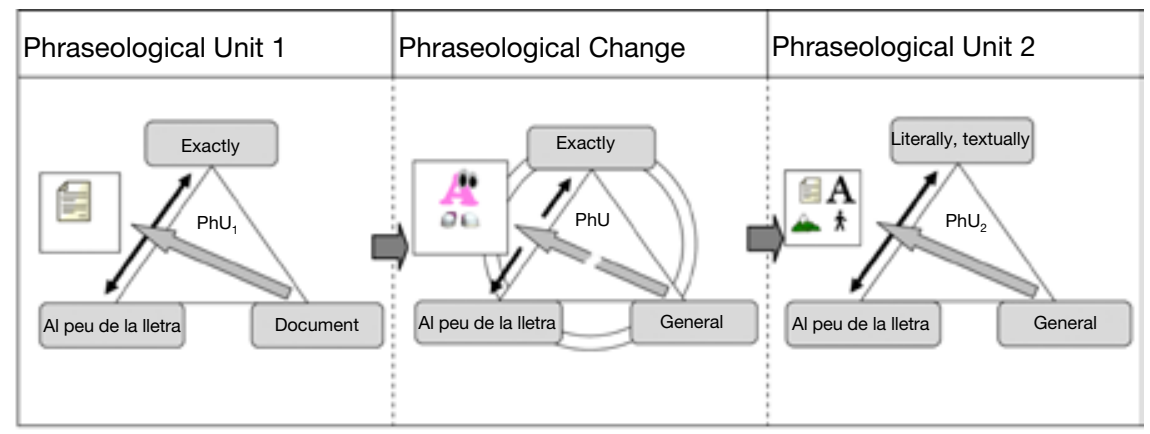

Language (semantic) change

Historical change

Figure 2. Phraseological change.

22. Fleischer (1982: 193-194) \& Barz (1985: 193) refer to this process as "secondary phraseologization". 
created somewhere in the past, which means that Reality, as well as Language have changed since then. These changes affect the relation between the three parts of the $\mathrm{PhU}$ (and the Image, the component holding them together).

At stage 3, speakers cannot see the physical situation anymore. The letter [document] is not present and at the foot of a letter is perceived as a unit. Thus, the primary interpretation of the unit, the Image, is a letter with feet. Since the non-compositional reading is not compatible to reality, speakers identify it as a figurative meaning and tend to make sense of it by means of analogy. Since the speaker knows that al peu de la muntanya 'at the foot of the mountain' implies proximity and that a document has letters on it, he concludes the expression means [proximity to a document], ie, literally, textually. The existence of the PhU a la lletra, ad litteram [to the letter] favours this reading. Therefore, a new meaning arises $(5 a, b)$.

(5) a. Y allargántmela 'ns despedirem, prometent, per ma part, retornarlhi aquella á la major brevetat. Esta, copiada al peu de la lletra, estaba concebuda en los termes següents. "A En Llorens del Puig."

"And giving it [the letter] to me, we said goodbye, promising, on my side, to give it back to her as soon as possible. It, copied at the foot of the letter [literally], was written in the following terms. "To Mr. Llorens del Puig."”

(1880) La familia del Mas dels Salzers, Gayetà Vidal de Valenciano (CTILC)

b. Repetirem ara copiantlas y traduhintlas al peu de la lletra las no menos memorables paraulas de un mestre de la ciencia de la Administració, de Sir Henry Cole

'We will now repeat, copying and translating them at the foot of the letter [literally], the non less memorable words of a master of Administration science, of Sir Henry Cole'

\subsection{Summing up}

Since Phraseologization is a long process, in this case starting in the $15^{\text {th }}$ century, we present a summing up table with its key elements. We include: the different stages regarding phraseology and diachronic linguistics, the Form of the combination at each stage, its Phraseological meaning, the relevant utterance-type context and the Image emerging at each step. 
Table 4. Phraseologization process of al peu de la lletra

\begin{tabular}{|c|c|c|c|c|}
\hline \multicolumn{5}{|c|}{ Phraseologization: al peu de la lletra } \\
\hline $\begin{array}{l}\text { Stages } \\
\text { (phraseology) }\end{array}$ & $\begin{array}{l}\text { 1. Free Word } \\
\text { combination }\end{array}$ & $\begin{array}{l}\text { 2. Restricted Word } \\
\text { combination }\end{array}$ & $\begin{array}{l}\text { 3. Phraseological } \\
\text { Unit with figurative } \\
\text { meaning }\end{array}$ & $\begin{array}{l}\text { 4. Frozen } \\
\text { Phraseological Unit }\end{array}$ \\
\hline $\begin{array}{l}\text { Stages } \\
\text { (diachronic }^{\text {linguistics) }}\end{array}$ & Initial stage & Bridging context & Switch context & Conventionalization \\
\hline Form & Al peu de & $\begin{array}{l}\text { [s.th. important] } \\
\text { al peu de [a legal } \\
\text { document] }\end{array}$ & $\begin{array}{l}\text { Complir [les } \\
\text { instruccions] } \\
\text { al peu de la lletra }\end{array}$ & $\begin{array}{l}\text { Complir les } \\
\text { instruccions } \\
\text { al peu de la lletra }\end{array}$ \\
\hline \multirow{3}{*}{$\begin{array}{l}\text { Phraseological } \\
\text { meaning }\end{array}$} & \multirow{3}{*}{$\varnothing$} & \multirow{3}{*}{$\begin{array}{l}\text { At the end of the } \\
\text { document }\end{array}$} & \multirow[t]{3}{*}{ Exactly } & Exactly \\
\hline & & & & Literally \\
\hline & & & & Textually \\
\hline \multirow{6}{*}{$\begin{array}{l}\text { Utterance-type } \\
\text { context }\end{array}$} & \multirow{3}{*}{ Unconstrained } & \multirow[t]{3}{*}{ (still not a unit) } & (as a unit) & (as a unit) \\
\hline & & & \multirow[t]{2}{*}{ Complir } & Complir \\
\hline & & & & Copiar \\
\hline & Unconstrained & Legal texts & $\begin{array}{l}\text { Used in new } \\
\text { communication } \\
\text { contexts }\end{array}$ & Unconstrained \\
\hline & \multirow[t]{2}{*}{ Not relevant } & Handwriting & \multirow{2}{*}{$\begin{array}{l}\text { Previous context } \\
\text { conventionalized } \\
\text { in the unit, but not } \\
\text { actively present } \\
\text { anymore }\end{array}$} & \multirow[t]{2}{*}{ Typing } \\
\hline & & $\begin{array}{l}\text { Dispositions at } \\
\text { the end of legal } \\
\text { documents }\end{array}$ & & \\
\hline \multirow[t]{2}{*}{ Image } & \multirow[t]{2}{*}{$\begin{array}{l}\varnothing \\
\text { (Source meaning) }\end{array}$} & $\begin{array}{l}\text { Image: end of } \\
\text { document }\end{array}$ & $\begin{array}{l}\text { Image: a letter with } \\
\text { feet }\end{array}$ & \multirow[t]{2}{*}{$\begin{array}{l}\varnothing \\
\text { (Target meaning2) }\end{array}$} \\
\hline & & $\begin{array}{l}\text { (Target meaning } 1 \\
\text { foregrounded) }\end{array}$ & $\begin{array}{l}\text { (Source meaning } \\
\text { backgrounded) }\end{array}$ & \\
\hline
\end{tabular}

* Stages of acquisition of grammatical meaning according to Heine (2002: 86).

\section{Concluding remarks}

Phraseological Units, far from being anomalous, are quite ordinary language items underlying semantic change.

Phraseology is the ideal "test bench" to prove the general validity of the Invited Inferencing Theory of Semantic Change. Since Phraseological Units carry a heavier semantic load, the conventionalized implicatures are more visible in them than in other language elements. Therefore, the different change stages are also more evident.

A prototypical context description is essential to understand the process. In fact, the initial context is part of the unit because it becomes conventionalized, although speakers do not always know how to interpret it. In these cases, the Image arising is also an important factor leading to semantic change. 


\section{References}

Baranov, A. \& Dobrovol'skij, D. (1996). «Idiomatichnost' i idiomy», Voprosy jazykoznanija 5, pp. 51-64. [cited by Timofeeva (2012)]

Barcelona Sánchez, A. (2000). Metaphor and metonymy at the crossroads. A cognitive perspective. Berlin and New York: Mouton de Gruyter.

Barz, Irmhild (1985). «Primäre und sekundäre Phraseologisierung». In: Fleischer, Wolfgang (ed.). Textbezogene Nominationsforschung. Studien zur deutschen Gegenwartssprache. Akademie der Wissenschaften der DDR. Zentralinstitut für Sprachwissenschaft. Linguistische Studient, Reihe a, 123. Berlin, pp. 119-140.

Buenafuentes de la Mata, Cristina (2002). «Procesos de gramaticalización en el estudio de los compuestos del español: el caso del elemento mal/a(-)». Anuari de Filologia: XXIII-XIV, pp. 11-12. Barcelona: Universitat de Barcelona.

Burger, Harald (1996). Phraseologie: ein internacionales Handbuch zeitgenössischer Forschung. Berlin: De Gruyter.

Burger, Harald (2010). Phraseologie: eine Einführung am Beispiel des Deutschen. Berlin: Erich Schmidt.

Bybee, Joan. (2007). Frequency of Use and the Organization of Language. Oxford: Oxford University Press.

Corpas, Gloria (1996). Manual de fraseología española. Madrid: Gredos.

Cuenca, M. Josep (2000). «L'estudi de les construccions idiomàtiques des de la lingüística cognitiva i l'anàlisi contrastiva». In: Salvador, Vicent \& Piquer, Adolf (eds.) El discurs prefabricat. Estudis de fraseologia teòrica i aplicada. Castelló: Publicacions de la Universitat Jaume I, pp. 33-48.

Dobrovol'skij, Dmitrij and Piirainen, Elisabeth (2005). Figurative language: cross-cultural and cross-linguistic perspectives. Oxford: Elsevier.

Dräger, Marcel (2012). «Plädoyer für eine diachrone Perspektive in der Phraseographie». In: Filatkina, Natalia; Kleine-Engel, Ane; Dräger, Marcel \& Burger, Harald (ed.): Aspekte der historischen Phraseologie und Phraseographie. Heidelberg: Winter, pp. 193-226.

Fleischer, Wolfgang (1982). Phraseologie der deutschen Gegenwartssprache. Leipzig.

Garachana, Mar (2012). Teoría de la gramaticalización. Estado de la cuestión. Unpublised masnuscript, Universitat de Barcelona. <http://www.academia. edu/11963627/Teor\%C3\%ADa_de_la_Gramaticalizaci\%C3\%B3n._Estado_de_ la_cuesti\%C3\%B3n>

Garachana, Mar (2014). «Gramática e historia textual en la evolución de los marcadores discursivos. El caso de no obstante». Rilce: Revista de Filología Hispánica 30.3: 959-984.

Garachana, Mar and Rosemeyer, Malte (2011). «Rutinas léxicas en el cambio gramatical. El caso de las perífrasis deónticas e iterativas». Revista de Historia de la Lengua Española 6, pp. 35-60.

Heine, Bernd; Claudi, Ulrike and Hünnemeyer, Friederike (1991). Grammaticalization: A conceptual framework. Chicago: University of Chicago Press.

Heine, Bernd and Kuteva, Tania (2002). World Lexicon of Grammaticalization. Cambridge: Cambridge University Press.

Hopper, Paul and Traugott, Elizabeth C. (1993/2003). Grammaticalization. Cambridge: Cambridge University Press.

Horn and Ward (eds.) (2004). The Handbook of Pragmatics. Oxford: Blackwell. 
Howarth, Peter (2000). «Describing diachronic change in English phraseology». In: Corpas, Gloria (ed.): Las lenguas de Europa: estudios de fraseología, fraseografía y traducción. Granada: Universidad de Granada, pp. 213-230.

Huang, Yan (2007). Pragmatics. Oxford: Oxford University Press.

IEC. Corpus Textual Infomatitzat de la Llengua Catalana (CTILC). (Ctilc.iec.cat, 22.05.2015).

Levinson, Stephen ([2000] 2004). Significados presumibles: la teoría de la implicatura conversacional generalizada. Madrid: Gredos.

Lewandowska-Tomaszczyk, Barbara (1985). «On semantic change in a dynamic model of language». In: Fisiak, Jacek (ed.) Historical semantics. Historical WordFormation. Berlin: Mouton de Gruyter, pp. 297-323.

Martí Sánchez, Manuel (2005). «Explorando la definición real de los fraseologismos». Círculo de Lingüística Aplicada a la Comunicación (clac) 24. Madrid: Universidad Complutense de Madrid, pp. 47-73.

Martines, Josep (2000a). «L'expressió de les emocions i la creativitat lèxica: estimar 'amar', entre l'eufemisme i la metàfora cultural». In: Actas del VIII Congreso Internacional de la Asociación Hispánica de Literatura Medieval. Santander, setiembre, 1999. Santander: UIMP, pp. 1221-1243

Martines, Josep (2000b). «El canvi lèxic en català (ss. XVI-XX). Una aproximació des de la lexicologia diacrònica cognitiva (i). Les novetats i la llengua catalana». In: Jornades de la Secció Filològica de l'Institut d'Estudis Catalans a la Universitat d'Alacant el dia 16 d'octubre de 1998. Barcelona: IEC, pp. 35-64.

Martines, Josep (2012a). «La integració conceptual o blending i l'arc de Sant Martí. Vers una semàntica cognitiva diacrònica i cultural», eHumanista-IVITRA, 2, p. 240-270

Martines, Josep (2012b). «El canvi semàntic a propòsit de enze, enza. Estudi del lèxic d'Enric Valor». Ítaca. Revista de Filologia, 2, pp. 143-204.

Martines, Josep (2013). «El verb estimar i l'amor hereós i Joan Roís de Corella. Un acostament segons la pragmàtica diacrònica», Afers, 76, pp. 717-739.

Martines, Josep (forthcoming). «Diacronia i neologia: canvi semàntic, subjectivació i representació del pensament. El català esmar, des de 'taxar' fins a 'inferir' i 'imaginar' i més enllà». Caplletra 59.

Martines, Josep (forthcoming). «L'émergence des futurs épistémiques romans. L'exemple du catalan médiéval du XIIIème siècle». In: Laura Baranzini et al. (ed.), Le futur dans les langues romanes, Peter Lang.

Martines, Vicent (dir.). Corpus Informatitzat de la Gramàtica del Català Antic (CIGCA).

Martines, Vicent (dir.). Corpus Informatitzat de la Gramàtica del Català Modern (CIGCatMod).

Meillet, Antoine (1912/1958). «L'evolution des formes gramaticales». Scientia, 12(6), pp. 384-400 (reimpr. Meillet 1958: 130-148).

Meillet, Antoine (1958). Linguistique historique et linguistique générale. Paris: Champion.

Narrog, Heiko and Heine, Bernd (eds.) (2011a): The Oxford Handbook of Grammaticalization. Oxford: Oxford University Press.

Narrog, Heiko \& Heine, Bernd (eds.) (2011b). «Introduction». In: Narrog, Heiko \& Heine, Bernd (eds.). The Oxford Handbook of Grammaticalization. Oxford: Oxford University Press, pp. 1-16. 
Pérez Saldanya, Manuel (1997). «Entre el lèxic i la gramàtica: els processos de gramaticalització»». In: Cicle de conferències 95-96. Lèxic, corpus i diccionaris. Barcelona: Institut Universitari de Lingüística Aplicada (Universitat Pompeu Fabra), pp. 91-111.

Pérez Saldanya, Manuel and Vicent Salvador (1995). «Fraseologia de l'encara i processos de gramaticalització». Caplletra 18, pp. 85-108.

Piirainen, Elisabeth (2012). Widespread Idioms in Europe and Beyond. Toward a Lexicon of Common Figurative Units. New York: Peter Lang.

Ruiz Gurillo, Leonor (1997). Aspectos de fraseología teórica española. València: Universitat de València.

Ruiz Gurillo, Leonor (2001). «La fraseología como cognición: vías de análisis». Lingüística Española Actual XXIII.1, pp. 107-132.

Ruiz Gurillo, Leonor (2010). «Interrelaciones entre gramaticalización y fraseología en español». Revista de Filología Española XC 1: 173-194. $<$ http://dx.doi.org/10.3989/rfe.2010.v90.i1.201>

Sánchez López, Elena (2013). Estudi de la llengua d'Ausiàs March a través de les col·locacions. Una aproximación semiautomàtica. Boston/Berlín: De Gruyter.

Sánchez López, Elena and Fuster Ortuño, M. Àngels (2012). «La fraseologia vista des d'una doble perspectiva: sincrònica i diacrònica». eHumanista/IVITRA 2: 185-201 (http://www.ehumanista.ucsb.edu/eHumanista\%20IVITRA/index.shtml, 12.05.2015).

Sánchez López, Elena and Fuster Ortuño, M. Àngels (2014). «Estudi de les unitats fraseològiques de la tercera esfera des d'una perspectiva diacrònica». Caplletra 56, pp. 243-267.

Sánchez López, Elena and Lozano Sañudo, Belén (2015). «La traducción de unidades fraseológicas con sentido figurado: Cuando los árboles no nos dejan ver el bosque». Unpublished manuscript, Universitat d'Alacant.

Timofeeva, Larissa (2012). El significado fraseológico. En torno a un modelo explicativo y aplicado. Madrid: Liceus.

Traugott, Elizabeth (2010). «Grammaticalization». In: Jucker, Andreas H. \& Taavitsainen, Irma (eds.), Historical Pragmatics. Berlin: Mouton de Gruyter, pp. 97-126.

Traugott, Elizabeth (2004). «Historical Pragmatics». In Horn, Larry \& Ward, Gregory (eds.) The Handbook of Pragmatics. Oxford: Blackwell, pp. 538-61.

Traugott, Elizabeth C. \& Dasher, Richard B. (2002). Regularity in Semantic Change. Cambridge: Cambridge University Press.

Traugott, Elizabeth C. and Heine, Bernd (eds.) (1991). Approaches to Grammaticalization. Amsterdam: John Benjamins. 